\title{
ZARZACDZANIE MEDIAMI ELEKTRONICZNYMI Z WYKORZYSTANIEM TECHNOLOGII BLOCKCHAIN W KOMUNIKACJI NAUKOWEJ
}

\author{
Abstract \\ ELECTRONIC MEDIA MANAGEMENT WITH THE USE OF BLOCKCHAIN \\ TECHNOLOGY IN SCHOLARLY COMMUNICATION
}

Blockchain is a revolutionary technology, which has the potential to fundamentally change many areas of activities, including scientific research and scholarly communication, together with the publishing industry. This paper focuses on the blockchain's potential to transform scholarly communication and research in general. It highlights, how blockchain can touch many critical aspects of scholarly communication, including transparency, trust, reproducibility and credit. Moreover, blockchain could change the future role of every stakeholder, and it could have an important role in all research processes, not only scholarly communication. The paper shows that blockchain technology has the potential to solve some of the most prominent issues the scholarly communication is currently facing, such as issues around costs, trust and credibility, openness, and universal accessibility to scholarly information. The research presents basic information about blockchain technology. Based on the literature, an attempt was made to create a model, how to use this technology as a disruptive innovation in scholarly communication.

Keywords: blockchain technology, distributed ledger, scholarly communication, scientific information dissemination, scholarly publishing 


\section{Wprowadzenie}

Wielu autorów twierdzi, że obecnie publikowanie naukowe oraz, szerzej, komunikacja naukowa znajdują się w permanentnym kryzysie (Prosser, 2003; Sompel, 2004; Cisek, Sapa, 2007; Coelho, Brandão, 2019; Jaradeh i in., 2019). Część tych problemów ma przyczyny obiektywne, takie jak na przykład gwałtowny przyrost publikacji, sięgający 8-9\% rocznie, co powoduje podwajanie liczby publikacji co dziewięć lat (Noorden, 2014). Znaczna część problemów jest powodowana przez nowe technologie informacyjne, które bywają na przykład wskazywane przez wydawców jako jedna z przyczyn gwałtownego wzrostu cen czasopism naukowych (Liu, Gee, 2017). Można mieć jednak nadzieję, że - tak jak w wielu innych przypadkach - dobrym lekarstwem na problemy stwarzane przez nowe technologie są... jeszcze nowsze technologie. Taka sytuacja może występować w przypadku zastosowania technologii blockchain $\mathrm{w}$ zarządzaniu mediami elektronicznymi w wielu dziedzinach, w tym w obszarze wybranym dla celów tego artykułu - komunikacji naukowej. Technologia blockchain, stworzona przez twórcę bitcoina, Satoshiego Nakamoto ${ }^{1}$ (2008), jest stosowana do zapewnienia bezpieczeństwa transakcji pomiędzy firmami w biznesie. Często jest ona nazywana innowacyjną, a nawet rewolucyjną ze względu na rolę, jaką może odgrywać w dokonaniu fundamentalnych zmian w wielu tak różnych dziedzinach gospodarki i życia społecznego, jak bankowość, przemysł fonograficzny, edukacja oraz zarządzanie mediami, między innymi w komunikacji naukowej (Rossum, 2017).

Według Swan i de Filippi (2017) pojawienie się technologii blockchain (łańcucha bloków), zwanej też distributed ledger (rozproszony rejestr) powoduje rozpoczęcie nowej ery w sieciowym przetwarzaniu informacji, charakteryzującej się bezpiecznym, bezpośrednim i zwalidowanym transferem informacji w sieciach inteligentnych, nazywanych tak w celu odróżnienia ich od internetu, czyli „tradycyjnej” sieci. Inteligencja jest wbudowana w działania sieci dzięki użyciu skomplikowanego protokołu, który automatycznie identyfikuje, waliduje, potwierdza i wykonuje transakcje w sieci. W rezultacie powstaje nowa forma "algorytmicznego zaufania”, które zasadniczo różni się od tradycyjnego rozumienia zaufania, dotyczącego relacji między ludźmi. To oznacza, że tradycyjni pośrednicy służący weryfikacji i walidacji transakcji stają się nieużyteczni, a instytucjonalna struktura społeczeństwa opiera się na procesach komputerowego przetwarzania informacji.

Komunikacja naukowa, jako element procesu naukowego, obejmuje społeczne procesy (formalne i nieformalne) rozpowszechniania wyników badań naukowych pomiędzy naukowcami ${ }^{2}$, związane z przetwarzaniem informacji naukowej. W trakcie tych procesów dokonuje się wiele transakcji, których uczestnicy powinni

1 Uważa się, że jest to pseudonim osoby lub grupy osób, które wprowadziły tę kryptowalutę do użytku w 2009 roku (Markowski, 2019).

2 Pomijam tu procesy tzw. komunikowania o nauce, służące wymianie informacji pomiędzy naukowcami a ogółem społeczeństwa (popularyzacja nauki), w tym między innymi decydentami. 
być jednoznacznie identyfikowalni, a wyniki powinny być, w zależności od sytuacji, albo łatwe do uzyskania dla wszystkich, albo wprost przeciwnie - udostępniane tylko osobom uprawnionym. Dodatkowo transakcje realizowane w komunikacji naukowej są przedłużeniem i rezultatem transakcji realizowanych w nauce ogólnie, na przykład podczas uzyskiwania grantów i prowadzenia badań laboratoryjnych. Obecnie interakcje osób uczestniczących w tych transakcjach wciąż są oparte na technologiach uciążliwych w stosowaniu, niezapewniających właściwych cech relacji i transparentności, takich jak internetowe systemy obsługi procesów wydawniczych, w tym pozyskiwania tekstów od autorów, poczta elektroniczna, strony wydawców i czasopism, biblioteki cyfrowe i serwisy społecznościowe (np. blogi naukowe). Zastosowanie technologii blockchain w tym chaotycznym środowisku może ułatwić osiąganie transparentności oraz spowodować innowację zakłócającą procesów badawczych, poszukiwania informacji i udostępniania wyników badań naukowych.

Nowe rozwiązania technologiczne stwarzają możliwości istotnych zmian w procesach badawczych i komunikacji naukowej poprzez transformację skostniałych procesów i relacji pomiędzy ich uczestnikami. Według wielu opinii (Owen, 2007, s. 55; Casper, 2016, s. 95; Andersen, Lomborg, 2020, s. 50), zmiany w komunikacji naukowej dotyczą w małym stopniu cech gatunkowych publikacji, a bardziej sposobów rozpowszechniania, organizacji i wykorzystania informacji w środowisku cyfrowym. Zmiany te mogą prowadzić do powstania samoregulującego się ekosystemu komunikacji naukowej. Zastosowanie łańcucha bloków w tym zakresie jest obszarem intensywnie badanym (Janowicz i in., 2018; Novotny i in., 2018).

Artykuł ma charakter teoretyczny. Jego celem jest przedstawienie technologii blockchain jako źródła nowych sposobów zarządzania mediami ${ }^{3}$ elektronicznymi, jej możliwości, ograniczeń i potencjalnego wpływu na wybrany obszar zastosowań: komunikację naukową ze szczególnym uwzględnieniem publikowania naukowego, którego podstawą jest czasopiśmiennictwo naukowe. Osiągnięcie tego celu posłużyć ma weryfikacji hipotezy o przydatności technologii blockchain jako potencjalnego narzędzia służącego wprowadzaniu zmian o charakterze innowacyjnym w publikowaniu naukowym. W tym celu dokonano próby stworzenia modelu publikowania naukowego z zastosowaniem technologii blockchain, co wymaga określenia kierunków możliwych zmian, wynikających z zalet i wad technologii oraz wskazania nowych rozwiązań, których ona dostarcza, zarówno dla indywidualnych badaczy, jak i dla całej społeczności naukowej. Aby osiągnąć te cele, zastosowano przede wszystkim metodę analizy piśmiennictwa naukowego, dotyczącego zastosowania tej technologii w publikowaniu naukowym. Publikacji takich jest wciąż bardzo niewiele, a duża ich część stanowi teoretyczny opis potencjalnych implementacji. Dzięki wykorzystaniu tej metody możliwa była konfrontacja stanu wiedzy

3 Zarządzanie mediami jest tu rozumiane w ujęciu szerszym, dotyczącym mediów traktowanych jako dziedzina odnosząca się do zjawisk społecznych, politycznych i gospodarczych (Nierenberg, 2013, s. 46). 
prezentowanego $\mathrm{w}$ literaturze przedmiotu $\mathrm{z}$ badaniami własnymi autora, dotyczącymi zastosowania nowych mediów w komunikacji naukowej, w tym publikowaniu naukowym.

W dalszej części artykułu przedstawione zostaną możliwości i problemy związane $\mathrm{z}$ zastosowaniem nowej technologii w komunikacji naukowej. $\mathrm{W}$ pierwszej części skrótowo zaprezentowana została technologia blockchain, w takim rozmiarze, aby umożliwić dalsze dywagacje. Kolejna część dotyczy sposobów wykorzystania opisanej technologii $\mathrm{w}$ publikowaniu naukowym. To zastosowanie, bliskie autorowi artykułu, traktować można jako jedną z możliwości wykorzystania technologii w zarządzaniu mediami elektronicznymi, gdyż blockchain może być użyty w zarządzaniu tymi mediami we wszelkich działaniach. Na koniec przedstawiony zostanie potencjał innowacyjny technologii blockchain w procesach komunikacji naukowej.

\section{Technologia blockchain}

Blockchain jest technologią służącą do zdecentralizowanego, samoorganizującego się zarządzania informacją. Jest to sposób na zapis zaszyfrowanych informacji w „blokach” (tworzących „łańcuch”) na wielu urządzeniach, współwykorzystujących internet (Johnson, Manion, 2019, s. 10). Dlatego nazywa się ją także technologią rozproszonych rejestrów lub rozproszonej księgi głównej (ang. distributed ledger technology, DLT). Jest to rodzaj elektronicznej listy (bazy danych), na której zapisywane są chronologicznie wszystkie transakcje realizowane między użytkownikami (Dudek, 2017, s. 56). Można także stwierdzić, że łańcuch bloków jest zdecentralizowaną siecią typu peer-to-peer (P2P), tworzącą niezmienne, chronologicznie uporządkowane zapisy aktywów wraz z transakcjami (Mackey i in., 2019, s. 2). Transakcje są typowo związane $\mathrm{z}$ wymianą dokumentów lub informacji, często połączoną z przepływami finansowymi, realizowanymi przy pomocy kryptowalut. Informacja może dotyczyć wszystkiego: pieniędzy, danych naukowych lub fachowych (np. medycznych), procesów edukacyjnych (np. zdalne nauczanie), utworów wszelkiego rodzaju (np. muzyki), umów i porozumień itp. Działanie tej rozproszonej bazy danych opiera się na złożonych algorytmach i kryptografii. Dzięki ich stosowaniu informacja może być zarządzana i organizowana w rewolucyjnie nowy sposób: otwarty, niezmienny ${ }^{4}$, zweryfikowany i szeroko dostępny, a przy tym zdecentralizowany, bez potrzeby powoływania centralnych instytucji nadzorczych ${ }^{5}$.

Najlepiej widać to na przykładzie bezgotówkowych przepływów pieniężnych, które mogą być traktowane jako transfer informacji. Są one realizowane bez

4 Informacja umieszczona w łańcuchu bloków nie może być usunięta, co może być niezgodne z regulacjami prawnymi obowiązującymi w Unii Europejskiej (Johnson, Manion, 2019, s. 12).

5 Tym między innymi technologia blockchain różni się od technologii chmurowych. 
angażowania banków, w ciągu kilku sekund z jednego miejsca na świecie do dowolnego innego, i bezpłatnie. To samo dotyczy transferu informacji każdego rodzaju. Blockchain jest na przykład używany jako cyfrowy rejestr do zapisywania, transferu i weryfikacji własności aktywów (domów, pojazdów, akcji, obligacji, hipotek, ubezpieczeń, praw autorskich) oraz do zapewnienia integralności i autentyczności dokumentów wrażliwych lub zapisów (paszportów, wiz, praw jazdy, akt urodzin i zgonów, kontraktów, testamentów, patentów, publikacji naukowych (Kim, Laskowski, 2018)). Dzięki temu uczestnicy transakcji mogą budować i kontrolować własną tożsamość cyfrowąa . Połączone ze sobą bloki informacji tworzące łańcuch mogą być rozpowszechniane w węzłach, czyli wśród uczestników (np. węzły autorów, redaktorów, wydawców...) i są przedmiotem konsensusu ${ }^{7}$ w sieci. Każdemu węzłowi są nadawane są jednakowe uprawnienia (mają tę samą wagę) do dostępu do łańcucha i autoryzacji nowych transakcji (Fu, 2020).

Najlepiej znaną aplikacją tej technologii jest system płatności cyfrowych za pomocą kryptowalut Bitcoin ${ }^{8}$ lub Ethereum ${ }^{9}$ (do tej pory powstało wiele podobnych kryptowalut). Pozwalają one na dokonywanie transakcji finansowych pomiędzy stronami z użyciem własnej waluty (np. bitcoinów) w sposób autoryzowany i zakodowany z zastosowaniem cyfrowych podpisów w obszarze sieci P2P. Odbywa się to za pomocą rozproszonej księgi (rejestru), pojedynczego, stale aktualizowanego dokumentu, którego kopię posiada każdy zainteresowany i w którym są zapisane salda wszystkich rachunków. Transakcje zawierane w kryptowalutach są weryfikowane na podstawie skomplikowanych działan matematycznych i kryptograficznych przez tzw. „eksploratorów” lub „górników” (miners). Takie zwalidowane transakcje są następnie dodawane jako bloki danych do końca łańcucha podobnych bloków w regularnych (około 10-minutowych dla Bitcoin BTC) odstępach czasu i udostępniane w sieci. Po utworzeniu bloku powstaje bardzo bezpieczny kod, który służy wiązaniu z następnym blokiem, tworząc łańcuch bloków. W taki sposób powstaje niezmienny zapis transakcji, przechowywany w każdym węźle sieci uczestniczącym w transakcjach, co sprawia, że błędy są eliminowane mimo braku centralnego miejsca zarządzającego informacją. Można powiedzieć, że stanowi on niezawodne źródło prawdy (Novotny i in., 2018, s. 160).

Istniejące łańcuchy bloków mogą różnić się od siebie dwiema cechami: mogą zawierać uprawnienia lub nie mieć uprawnień oraz być publiczne (np. Bitcoin i Ethereum) bądź prywatne (np. Corda ${ }^{10}$ ). Ta druga cecha określa, kto może stosować

6 Tożsamość jest rozumiana jako zestaw atrybutów dotyczących jednostki (ISO/IEC 24760-1). Jednostka może mieć więcej niż jedną tożsamość, a kilka jednostek może mieć tę samą tożsamość.

Konsensus to proces, $w$ ramach którego zainteresowane strony zgadzają się na przeprowadzenie transakcji zatwierdzonej przez wszystkich uczestników sieci opartej na technologii blockchain.

8 Zob. https://bitcoin.org/.

9 Ethereum jest otwartą platformą dla realizacji inteligentnych kontraktów blockchain, obsługującą własną kryptowalutę: https://ethereum.org/.

10 Corda to otwarta platforma blockchainowa dla biznesu: https://www.corda.net. 
blockchain - dostęp do prywatnych bloków jest ograniczony tylko dla określonych grup podmiotów. O ile w łańcuchach publicznych uczestnicy transakcji są dla siebie nawzajem anonimowi, o tyle w prywatnych blockchain każdy uczestnik ma określoną tożsamość związaną ze wszystkimi zapisami przez niego stworzonymi. W łańcuchach bloków bez uprawnień w każdym węźle możliwe jest przeprowadzenie dowolnego działania, w tym dodawanie bloków do łańcucha, jest on więc udostępniany każdemu. W uprawnionych łańcuchach bloków pewne węzły wymagają zezwolenia na realizację określonych zadań.

Technologia blockchain jest rozwijana dla różnych zastosowań w obszarze aktywności cyfrowych, takich jak zarządzanie dokumentami edukacyjnymi i medycznymi, oraz wpływa na różne dziedziny gospodarki, takie jak działalność wydawnicza, handel i produkcja, łańcuchy dostaw, opieka zdrowotna i działalność agend rządowych. Z punktu widzenia potencjału oddziaływania tej technologii na funkcjonowanie wielu gałęzi przemysłu i działów gospodarki aktualny stan rozwoju blockchain jest porównywany z wczesnymi etapami rozwoju internetu (Rossum, 2017). Umożliwia ona każdej zainteresowanej jednostce (firmie, organizacji, osobie) przechowywanie własnych danych tożsamościowych na komputerach oraz udostępnianie ich do celów identyfikacji. W ten sposób jest zapewniana kontrola nad własną tożsamością w środowisku sieciowym oraz odpowiednie nią zarządzanie. $W$ razie potrzeby serwisy mogą żądać informacji bezpośrednio związanych z transakcją, mogą na przykład pytać o wiek kontrahenta (jego pełnoletniość), wykształcenie (uprawnienia wykonywania zawodu), akredytację (np. dziennikarską), narodowość itp.

Jak pisze Dudek (2017, s. 59) wdrożenie technologii blockchain będzie skutkować znacznymi korzyściami ekonomicznymi we wszystkich dziedzinach życia społecznego i gospodarczego - wszędzie tam, gdzie właściwe zarządzanie informacją elektroniczną pozwala obniżać koszty transakcji, przyśpieszać rozliczenia przy jednoczesnym wzroście przejrzystości, gdzie liczy się bezpieczeństwo oraz ograniczenie możliwości duplikowania dokumentów, a także wspomaganie innowacyjności. Strony transakcji otrzymują narzędzie wymiany informacji o usługach, produktach, działaniach szybciej, taniej, łatwiej i bezpieczniej przy wyższej jakości usług informacyjnych. Największą zaletą jest jednak możliwość uzyskania kontroli nad danymi poufnymi lub wrażliwymi (np. osobowymi) oraz zachowania tej poufności w realizowanych transakcjach.

\section{Elementy technologii blockchain w komunikacji naukowej}

Zastosowanie technologii blockchain w komunikacji naukowej można traktować jako przypadek zarządzania mediami elektronicznymi. Wymaga ono stworzenia modelu publikowania naukowego, uwzględniającego wszystkie występujące w nim etapy, realizowane w nich transakcje oraz uczestników (węzły) tych 
transakcji. Transakcje te są przeprowadzane w sposób otwarty (publiczny) lub zamknięty i opierają się na bezgotówkowym przepływie kryptowalut. Niezbędne jest także określenie sposobu zastosowania elementów technologii blockchain w każdym miejscu modelu.

Oczekuje się, że zastosowanie technologii blockchain w komunikacji naukowej pozwoli na rozwiązanie wskazanych poniżej problemów dzięki temu, że umożliwi głębszą współpracę pomiędzy badaczami, wydawcami, organizacjami finansującymi i innymi interesariuszami. Jednym z głównych celów stosowania technologii blockchain w badaniach naukowych jest zapewnienie wiarygodnej informacji o pochodzeniu wyników badań, wraz z informacją dotyczącą zmian tych aktywów w cyklicznych procesach badań naukowych. W coraz bardziej sieciowym środowisku komunikacji naukowej, składającym się z systemów zarówno fizycznych, jak i cyfrowych, w którym ludzie współpracują z maszynami, mechanizmy budowy zaufania i wiarygodności, takie jak blockchain, zyskują zasadnicze znaczenie (van Lier, 2017). Uzyskuje się przy tym takie korzyści, jak:

- Umożliwienie dostarczania do opublikowania tekstów i danych naukowych wraz z natychmiastowym potwierdzeniem istnienia autorów wskazanych w tekście i ich kompetencji.

- Zapewnienie wiarygodności publikowanym materiałom.

- Identyfikacja informacji naukowej w wersji elektronicznej (DOI).

- Zintegrowane udostępnianie publikacji i danych badawczych.

- Zapewnienie wiarygodności cytowaniom i odwołaniom do obcych prac.

- Stosowanie starych i nowych miar produktywności i cytowań.

- Budowa reputacji, informacja o poszczególnych badaczach (identyfikacja przez ORCID), instytucjach, laboratoriach, wydziałach i zespołach badawczych oraz ich produktywności naukowej.

- Globalne określanie reputacji i wiarygodności źródeł informacji i danych naukowych.

- Identyfikacja i eliminacja drapieżnych czasopism, konferencji i innych nieetycznych kanałów komunikacyjnych.

- Transparentność procesów recenzowania (zarówno otwartych, jak i „ślepych", przed opublikowaniem i po opublikowaniu tekstu).

- Możliwość skomunikowania się z recenzentami.

- Zarządzanie własnością intelektualną i licencjami, w tym dostęp otwarty i odpłatny.

Realizacja tych zastosowań technologii może skutkować powrotem do pierwotnych zasad prowadzenia otwartej aktywności naukowej i zdecentralizowanej działalności publikacyjnej, w której nie istnieją centralne ciała zarządcze, decydujące o wyborze wyników badań do opublikowania, a ocena osiągnięć jest rezultatem konstruktywnej krytyki ze strony specjalistów (Coelho, Brandão, 2019). Celem jest zapewnienie atrybucji i potwierdzonej wiarygodności wszystkich czynności wykonywanych podczas realizacji prac naukowych od samego początku tych procesów 
(np. wnioskowania o grant), poprzez włączenie do nich wszystkich niezbędnych urządzeń laboratoryjnych (w tym np. prowadzenia otwartych notatników laboratoryjnych), procesów publikacyjnych, aż po ich koniec (transakcje cytowań), umożliwienie gromadzenia wyników badań w postaci cyfrowej, wspieranie rozpowszechniania informacji oraz wzrost wpływu treści naukowych w środowisku badaczy. W procesach tych szczególną rolę powinny odegrać prywatne łańcuchy bloków i technologie oparte na tego rodzaju blockchain. Ich cechy powodują szczególną przydatność w komunikacji naukowej. W takich łańcuchach przeprowadzający transakcje są łatwo identyfikowalni, a ich działania ograniczane przez mechanizmy kontroli dostępu, co pozwala wyeliminować wiele ataków hakerskich. Ma to szczególne znaczenie w początkowej fazie stosowania technologii w publikowaniu naukowym, gdy jest ona implementowana indywidualnie przez poszczególnych wydawców lub grupy czasopism, a także naukowców uruchamiających tzw. start-upy służące wspomaganiu badań naukowych. W dalszej kolejności i dłuższym okresie poszerzenie zasięgu stosowania tej technologii może prowadzić do tworzenia publicznych łańcuchów bloków, opartych na konsensusie w zakresie większości organizacyjnych i finansowych zagadnień dotyczących publikowania naukowego. Powoduje to nie tylko integrację całego procesu badań, włącznie z publikowaniem, ale także ściślejszą współpracę całego środowiska naukowego.

Stosowanie technologii blockchain może być zbyt kosztowne dla wielu zastosowań komunikacji naukowej. Oprócz typowych kosztów, takich jak zakup odpowiedniego sprzętu, konieczne może być zatrudnienie specjalistów w zakresie kryptografii, konfiguracji sieci i budowy inteligentnych kontraktów ${ }^{11}$ (ang. smart contract). W celu zniwelowania tego problemu proponuje się rozwiązania chmurowe, od dawna stosowane $\mathrm{z}$ powodzeniem $\mathrm{w}$ wielu innych dziedzinach. Umożliwiają one z jednej strony łatwy dostęp użytkowników do tych technologii, a z drugiej zdalną obsługę techniczną. Stosując platformy chmurowe blockchain, użytkownicy mogą się skupić na innowacji publikowania naukowego i procesach transakcyjnych, natomiast dostawca usług chmurowych bierze odpowiedzialność za dostarczanie wysokiej jakości platformy blockchain. Takie rozwiązanie, nazywane BaaS (ang. blockchain-as-a-service) zwykle zapewnia dużą moc obliczeniową i silne zabezpieczenia przy wysokiej dostępności usług w globalnej chmurze publicznej. Zintegrowane środowisko BaaS może oznaczać przechowywanie globalnej informacji naukowej na jednej platformie bez względu na miejsce powstania informacji i interakcji towarzyszących tym procesom. Technologia blockchain pozwala na zdecentralizowany dostęp do tej samej informacji dla wszystkich zainteresowanych.

Obecnie udostępnianie wielu rodzajów danych i informacji, takich jak teksty publikacji, dane o cytowaniach, strony konferencyjne i czasopisma są zarządzane przez wiele niepowiązanych ze sobą platform. BaaS może ułatwić efektywną

11 Inteligentny kontrakt to program komputerowy, który automatycznie wykonuje zapisaną w nim umowę, jeśli są spełnione jej warunki. Działanie takiego kontraktu (programu) jest niemożliwe do zablokowania. 
integrację wszystkich tych i innych obszarów komunikacji naukowej. Łatwo można sobie wyobrazić system komunikacji naukowej oparty na BaaS, który jest dostępny dla każdego zainteresowanego, gdzie zapisywane w sposób rozproszony wyniki wszystkich procesów i działań, takich jak recenzowanie i stosowanie miar cytowań, cechują się wysoką wiarygodnością (Burley, 2018, s. 146). System taki pozwala nie tylko na bardziej efektywne i wysoce poufne zarządzanie informacją naukową, ale także wspiera współpracę pomiędzy naukowcami i wydawcami dzięki skutecznemu rozpowszechnianiu informacji.

Zasadniczą korzyścią ze stosowania technologii blockchain w komunikacji naukowej jest możliwość gromadzenia w ogólnie dostępnym rejestrze łańcucha bloków wielkiej ilości wiarygodnej informacji dotyczącej wszystkich aspektów procesu publikowania naukowego. Narzędzia analityczne wykorzystywane w blockchain umożliwiają wydobycie rzeczywistej wartości tej informacji (Dillenberger i in., 2019), poza prostym gromadzeniem danych o transakcjach. Narzędzia takie można zastosować na przykład w platformach do wygodnego operowania na blokach danych mających formę par klucz-wartość. Zawsze wtedy, gdy bezpieczeństwo i wiarygodność działań odgrywają istotną rolę, należy stosować ten sam model bezpieczeństwa i podobne ograniczenia, związane z zapewnieniem poufności. Najlepiej, gdy te same mechanizmy zapewnienia wiarygodności, stosowane w blockchain, są również wykorzystywane w analizach danych z łańcuchów. Analizy takie mogą mieć różne formy - od standardowych analiz opisowych po narzędzia oparte na uczeniu się maszynowym i prognozowaniu.

Technologia blockchain pozwala na tworzenie zaufanych repozytoriów informacji, umożliwiając dostęp do informacji z uwzględnieniem zasad prywatności. Osiąga się to przez tworzenie konstruktów modelujących stosowane aktywa oraz uczestników działań. Aktywa odnoszą się do fizycznych lub konceptualnych obiektów dotyczących obszaru działania, w którym jest stosowany łańcuch bloków, na przykład do publikowania naukowego. Mogą się one zmieniać wraz z ewolucją działań w danym obszarze. Wiele rozwiązań technologicznych wiąże się z grupami typów aktywów, w tym z gromadzoną informacją i możliwymi kierunkami rozwoju cyklu życia wykonywanych procesów. W aplikacjach związanych z publikowaniem naukowym typy aktywów będą dotyczyć takich obiektów, jak artykuły, zbiory danych z badań, recenzje i decyzje redakcji, prenumerata i transakcje dostępu. Uczestnikami są naukowcy (autorzy, recenzenci, redaktorzy), wydawcy, twórcy baz danych, funduszodawcy, pośrednicy i inni.

Współpraca z wykorzystaniem technologii blockchain może obejmować wielu uczestników (zarówno jednostki, jak i organizacje), którzy mają dostęp do informacji gromadzonej w wę́le. W tym przypadku zasadnicze znaczenie ma kontrola dostępu, realizowana z zastosowaniem wielu mechanizmów. Można na przykład wyspecyfikować grupy uczestników, którzy mają wyłączne prawo do przeglądania informacji i rozpoczynania transakcji. Innym rozwiązaniem jest przyznawanie praw dostępu na poziomie aktywów i ich atrybutów, na przykład w taki sposób, 
że redaktor może widzieć recenzję artykułu i nazwisko recenzenta, autor natomiast może widzieć tylko tekst recenzji bez nazwiska osoby oceniającej. Uczestnicy mają także dostęp do inteligentnych kontraktów wykonywanych w łańcuchu bloków. Kontrakty te mogą określać sposób funkcjonowania aktywów w trakcie ich cyklu życia, na przykład to, że po dostarczeniu końcowej recenzji jest ona przekazywana do redaktora, który podejmuje decyzję o dalszych działaniach, a także ograniczenia dotyczące aktywów lub relacji między nimi, na przykład artykuły opisujące eksperymenty muszą zawierać wszystkie dane ich dotyczące, które mają być umieszczone w łańcuchu bloków przed rozpoczęciem recenzowania. Kontrakty mogą być przeglądane i uzgadniane przez uczestników transakcji, co zapewnia transparentność i kontrolę nad przetwarzaniem danych umieszczonych w łańcuchu bloków. Informacje o uczestnikach i ich rolach $\mathrm{w}$ procesie publikacyjnym mogą być umieszczane w sieci z zastosowaniem technologii Linked Data. Dane te (oraz metadane), wraz z ontologiami modelującymi przepływy informacji w nauce, powinny być odpowiednie dla reprezentacji danych odpowiednich do gromadzenia w łańcuchu.

Metadane artykułu, takie jak tytuł, słowa kluczowe, abstrakt, rodzaj publikacji i liczba słów w tekście, mogą być wykorzystane podczas wyszukiwania informacji do automatycznego wskazywania tytułów czasopism, odpowiednich do zapytania wyszukiwawczego z punktu widzenia przedmiotu, długości i formatu tekstu. Można tego dokonać, stosując metody analizy danych, przetwarzania języka naturalnego i nauczania maszynowego. Podobne działania zostały przewidziane przez projektantów systemu JANE ${ }^{12}$ do obliczania stopnia podobieństwa przez porównywanie tytułów, słów kluczowych lub abstraktów wpisywanych przez użytkowników systemu z zawartością czasopism grupy PubMed. System proponuje czasopismo, autorów lub artykuły podobne do tekstu wprowadzonego przez użytkownika. Również wydawcy, tacy jak Taylor \& Francis ${ }^{13}$ oraz Springer ${ }^{14}$, oferują podobne rozwiązania.

Zastosowanie łańcuchów bloków może się łączyć z wykorzystaniem kryptowaluty, ogólnego stosowania lub stworzonej specjalnie do określonego zastosowania, co powoduje uwzględnienie aspektu ekonomicznego w blockchain. Zastosowanie kryptowaluty może pozwolić na przekazywanie mikropłatności wydawcom, a także posłużyć do konstruowania systemu nagród finansowych dla naukowców. Kryptowaluty mogą być także stosowane do finansowania całych projektów badawczych. W ten sposób w nauce zastosowanie może znaleźć kryptoekonomia, odzwierciedlająca liczbowo i finansowo miary wartości większości działań podejmowanych w nauce.

12 Zob. https://jane.biosemantics.org/.

13 Zob. https://authorservices.taylorandfrancis.com/journal-suggester/.

14 Zob. https://journalsuggester.springer.com/. 
Odpowiednie fundusze mogłyby trafiać do systemu niejako przekazywane przez autora wraz z tekstem dostarczonym do redakcji czasopisma ${ }^{15}$. Powinna to być kwota określonej wysokości, na przykład 100 jednostek wybranej kryptowaluty. Kwoty te mogłyby pochodzić na przykład z funduszy publicznych przeznaczonych na prowadzenie badań. Podobnie system komunikacji naukowej działa obecnie, gdyż fundusze na prenumeratę czasopism są rozdzielane centralnie ${ }^{16}$. Wysokość kwoty mogłaby być także uzależniona od kwot uzyskanych przez naukowców w poprzednich procesach publikacyjnych (Rossum, 2017, s. 11), dzięki czemu naukowcy, których publikacje osiągnęły dotąd większe zainteresowanie, zyskają większy wpływ na społeczność badaczy. Niektórzy proponują uwzględnienie w tym miejscu systemu roli wydawców, którzy mogliby udostępniać określoną liczbę jednostek kryptowaluty proporcjonalnie do liczby opublikowanych artykułów i wysokości subskrypcji czasopisma (Tarkhanov, Fomin-Nilov, Fomin, 2021, s. 255). Wówczas autorzy otrzymywaliby określoną kwotę od wydawcy. Kwota na przykład 100 jednostek kryptowaluty byłaby następnie rozdzielana na kolejnych etapach cyklu wydawniczego, a więc byłyby opłacane działania redaktora, recenzentów, komentatorów, wydawcy ${ }^{17}$ itp. Część kwoty mogliby otrzymywać także autorzy cytowani w artykule przygotowywanym do publikacji (Niya i in., 2019). W przypadku pozostawania po opublikowaniu pracy niewykorzystanej części kwoty, trafiałaby ona na tzw. loterię, skąd byłaby rozlosowywana wśród społeczności osób funkcjonujących w komunikacji naukowej (Janowicz i in., 2018, s. 550). Otrzymane jednostki kryptowaluty mogą być wymieniane na inne kryptowaluty lub waluty tradycyjne. Gdyby wysokość kwoty pobieranej podczas przyjmowania tekstu wynikała z nakładu pracy ponoszonej podczas zaplanowanych procesów, a nie jedynie z założonej stopy zysku wydawcy, to konsensus w tym zakresie pozwoliłby na wyznaczenie rzeczywistych kosztów publikowania. Byłby to dodatkowy czynnik wzmacniający efektywność ekonomiczną stosowania technologii blockchain w komunikacji naukowej.

Zauważmy, że propozycje tego rodzaju opierają się na tradycyjnym cyklu publikowania, który uwzględnia między innymi recenzowanie tekstów przez ekspertów: doświadczonych (utytułowanych) naukowców. Takie podejście konserwuje jednak paradygmaty w dyscyplinach naukowych, utrudniając ich przełamanie, co może spowalniać rozwój nauki. Proces wydawniczy jest organizowany przez wydawców. Mikropłatności z kolei pozwalają co prawda pominąć tradycyjnych wydawców, oskarżanych o wywołanie kryzysu czasopism, lecz z drugiej strony zostaje utracony mechanizm kontrolny pozwalający ograniczyć zachowania nieetyczne. Taki sposób

15 Nie musi tu chodzić tylko o artykuły naukowe. Podobnie może być finansowane rozpowszechnianie danych badawczych, wpisów w mediach społecznościowych, oprogramowania itp.

16 Fundusze te są rozdzielane centralnie na uczelnie i ich biblioteki, indywidualni naukowcy ich nie otrzymują. W uzyskiwanych grantach na badania często natomiast przewiduje się kwoty na przygotowanie publikacji.

17 Może to dotyczyć takich działań jak np. tworzenie analiz statystycznych, wymiana sprzętu laboratoryjnego, współpraca w organizacji procesu badawczego. 
finansowania może także spowodować wzrost wpływów podmiotów prywatnych, szczególnie dużych korporacji, na naukę z wszystkimi tego negatywnymi konsekwencjami. Dlatego też ważne byłoby łączenie technologii blockchain z nowymi, innowacyjnymi rozwiązaniami organizacyjnymi, których implementację technologia ta może wspierać.

\section{Innowacyjność technologii blockchain w komunikacji naukowej}

Zastosowanie technologii blockchain w komunikacji naukowej implikuje budowę skomplikowanego modelu publikowania naukowego przyszłości. W takiej sytuacji często posługujemy się metaforami konceptualnymi (Lakoff, Johnson, 2011), które pomagają zrozumieć nowe zjawiska. Jedną z takich metafor, dotyczącą rozwiązań technicznych, jest traktowanie blockchain jako protokołu sieciowego nowej generacji, pozwalającego na zapisywanie, transfer i weryfikację informacji o aktywach fizycznych lub cyfrowych. Z punktu widzenia zastosowań w komunikacji naukowej technologię tę można konceptualizować jako dwojakiego rodzaju innowację: podtrzymującą lub zaburzającą (Bower, Christensen, 1995). Ta pierwsza dotyczy nowej, ulepszonej wersji produktu, który jest już znany. Ta druga oznacza stworzenie całkowicie nowego produktu powodującego zniszczenie środowiska stosowania dotychczasowej technologii, z którego gruzów wyłania się nowe, konkurencyjne środowisko. Z punktu widzenia innowacji podtrzymującej można traktować technologię blockchain jako kolejny sposób naukowego publikowania elektronicznego. Z punktu widzenia innowacji zaburzającej możemy mówić o programowalnych publikacjach, czyli tych, których wszystkie parametry można konfigurować: to, kto może ich używać, jak, gdzie, w jakim celu oraz jakie są kolejne etapy cyklu życia publikacji, w tym determinanty czasowe, dystrybucja i przepływy płatności. W odróżnieniu od obecnych publikacji cyfrowych, które reprezentują tradycyjne gatunki tekstu w formacie elektronicznym (króluje tu format pdf), możliwość programowania publikacji i jej uruchamiania jako aplikacji jest nową cechą publikowania, wcześniej niedostępną.

David Kochalko (2019, s. 200) twierdzi, że technologia blockchain może pozwolić na osiągnięcie celów twórców pierwszych indeksów cytowań, z Eugene’em Garfieldem na czele. Chcieli oni stworzyć narzędzie uniwersalne: rozszerzyć zasięg tych baz danych na całość światowych publikacji naukowych, co przy zastosowaniu ówczesnych technologii i metod organizacji (w tym sposobów finansowania) nie było możliwe. Problem pogłębił się wraz z rozwojem internetu i bogactwem nowych gatunków tekstu elektronicznego, stosowanych w nauce. Zasoby te pozostają poza zasięgiem tych baz danych, co utrudnia rozwój wiedzy, gdyż cytowania można traktować jako walutę nauki. Można powiedzieć, że naukowcy wnoszą opłaty, w formie cytowań, swoim poprzednikom. Na tym między innymi polegają ograniczenia rozwojowe współczesnej nauki: rozpowszechnianie wyników badań 
pochłania czas i środki niezbędne do zakończenia formalnego cyklu wydawniczego, a następnie tylko część publikacji jest indeksowana w bazach danych (czyli możliwa do wyszukania). Dopiero nowa technologia umożliwia naukowcom zdobycie uznania (jednoznaczna atrybucja autorstwa) za ich wszystkie twórcze dzieła, w czasie rzeczywistym i niezależnie od statusu publikacji. Jednocześnie osoba poszukująca informacji ma natychmiastowy i uprawniony dostęp do wszystkich zasobów umieszczonych w łańcuchu (do tekstów, danych, ilustracji, materiałów roboczych) w czasie rzeczywistym, co może wpływać na obniżenie poziomu wykluczenia cyfrowego (Hughes, 2017).

Zastosowanie łańcuchów bloków w publikowaniu naukowym może spowodować istotne transformacje procesów tego publikowania, co powoduje opinie o przełomowym znaczeniu tej technologii zakłócającej w rozumieniu teorii innowacji (Raynard, 2017). Część tych procesów występuje w każdej działalności biznesowej, na przykład działania na rzecz wzrostu efektywności oraz ograniczania zaległości dotyczących fakturowania i płatności. Innym przykładem takich procesów może być tworzenie analiz dotyczących procesów realizowanych w organizacjach przy jednoczesnej ochronie prywatności jednostek. Inne procesy są bardziej specyficzne dla publikowania naukowego. Tu można wyróżnić dwa obszary: koordynację i organizację publikowania naukowego oraz rozpowszechnianie i zarządzanie treściami (Rubel, 2019). Obszary te mogą obejmować na przykład tworzenie bardziej transparentnych, wiarygodnych i kontrolowanych procedur recenzowania, zawierających elementy oceny aktywności recenzentów oraz ekspertyz jako narzędzia wspomagającego decyzje redaktora. Oznacza to istnienie dwóch obszarów zastosowania technologii, będących w centrum zainteresowania komunikacji naukowej: ogólnej i specyficznej dla tego zastosowania. Dla obu środowisko stosowania technologii łańcuchów bloków może dostarczyć wiarygodnych, efektywnych kosztowo i zrównoważonych działań, znacznie wzmacniając dostępność możliwości nieosiągalnych dla obecnych technologii.

Jak wynika z poprzedniej części artykułu, atrakcyjność łańcucha bloków dla gospodarki jest powodowana nadzieją na stworzenie systemu danych stabilnych, transparentnych i zdecentralizowanych. W nauce największe nadzieje budzi jednak nie tyle zarządzanie danymi, ile atrakcyjność społeczna nowej technologii (Jun, 2018). Z tej perspektywy głównymi zaletami technologii blockchain, oprócz niezmienności i weryfikowalności danych, jawią się takie możliwości, jak zapewnienie wiarygodności w środowisku charakteryzującym się jej niedostatkiem oraz zapewnienie oceny jakości bez potrzeby ustanawiania centralnej instytucji zarządzającej (Kosmarski, Gordiychuk, 2020, s. 335). Janowicz i in. (2018, s. 546) przedstawili obszary, w których nauka może skorzystać na stosowaniu technologii blockchain. Dotyczą one takich innowacyjnych rezultatów, jak:

- Transparentność procesu wydawniczego publikacji naukowych przez opisanie go w inteligentnych kontraktach i zastosowanie płatności w kryptowalutach. 
- Zarządzanie danymi z badań, co ułatwia dostęp do nich, a przez to zwiększa wiarygodność i powtarzalność badań.

- Tworzenie powiązań pomiędzy naukowcami i funduszami na badania, pozwalających na obsługę zarówno ofert ze strony naukowców, jak i zamówień ze strony grantodawców.

- Zarządzanie prawami autorskimi, zapewnienie jednoznacznej identyfikacji.

- Demokratyzacja nauki poprzez zwiększenie transparentności procesów podejmowania decyzji dotyczących rozdziału funduszy, oceny publikacji, organizowania konferencji, przyznawania nagród, również przez dopuszczenie bezpośrednio przedstawicieli społeczności naukowej do ocen w formie głosowań.

- Przyśpieszenie realizacji procesów cyklu wydawniczego.

- Transparentność oceny wpływu publikacji i naukowców (cytowania, miary alternatywne, w tym związane $\mathrm{z}$ użytkowaniem publikacji).

Z wyliczenia tego wyłania się obraz zmian wynikających z zastosowań technologii blockchain w nauce ogólnie i komunikacji naukowej w szczególności. Duże znaczenie może mieć zwłaszcza stworzenie środowiska, w którym będzie możliwe rozproszone zarządzanie nauką dzięki osiągnięciu konsensusu dotyczącego zasad i norm obowiązujących w komunikacji naukowej, w tym w publikowaniu naukowym.

Jednym z efektów tych zastosowań jest wiarygodna weryfikacja danych źródłowych, algorytmów, wyników pośrednich i informacji opublikowanej. Sieć łańcuchów bloków, zarządzanych przez światowe uczelnie wyższe, branżowe laboratoria badawcze, agendy rządowe, towarzystwa naukowe i fachowe oraz przez wydawców mogą stanowić wiarygodną, neutralną płaszczyznę dla tego typu informacji „proweniencyjnej" zarówno dla poszczególnych dyscyplin, jak i w skali interdyscyplinarnej. Nie wszystkie informacje muszą być przechowywane w łańcuchu bloków, wszystkie jednak muszą być tam odpowiednio reprezentowane. Treści umieszczone w łańcuchu nie mogą być zmieniane, uzyskuje się więc elektroniczną, ale niezmienną wersję publikacji, podobnie jak w druku. Nowe wersje mogą być dodawane do łańcucha - wówczas są przechowywane wszystkie wersje wzajemnie powiązane, a zatem widoczne są etapy prac nad tekstem lub zagadnieniem badawczym. Usprawni to na przykład proces recenzowania, umożliwi śledzenie badań dla uzyskania relewantnych materiałów źródłowych i pomoże uniknąć błędnych odsyłaczy do nieistniejących lub nieodpowiednich źródeł. Szczególne znaczenie ma dostępność takiej informacji proweniencyjnej dla artykułów w naukach eksperymentalnych, gdyż utrudnia fałszerstwa wyników uzyskanych w laboratoriach, przez co ogranicza rozpowszechnianie niepoprawnych wyników. Głównym składnikiem zarządzania wiarygodną informacją proweniencyjną będzie transparentność procesów służących gromadzeniu i zarządzaniu informacją. Transparentność ta będzie wynikać z logiki ogólnie dostępnych inteligentnych kontraktów. 
Badania naukowe, prowadzone $\mathrm{z}$ użyciem blockchain, mogą wywierać silny wpływ na sposoby uzyskiwania reputacji przez naukowców. Wielką zaletą tej technologii jest automatyczne archiwizowanie danych o wszystkich aktywnościach w węzłach. Reputacja może więc być oceniana na podstawie wykonanych transakcji i interakcji w społeczności naukowej (Zheng i in., 2018, s. 365). Zawsze wtedy, gdy naukowiec przekazuje dane z badań, przeprowadza analizy, na przykład statystyczne, pisze i przekazuje artykuł lub recenzję do wydawnictwa, działania te są automatycznie śledzone i zapisywane. Dzięki silnemu przeciwdziałaniu błędom i oszustwom znacznie łatwiejsze jest gromadzenie wiarygodnych i kompletnych informacji o aktywnościach badaczy, zespołów badawczych i instytucji naukowych. To z kolei pozwoli na tworzenie bardziej skomplikowanych i wiarygodnych miar oceny jakości, między innymi opartych na czynnościach dotąd słabo reprezentowanych w tym zakresie (np. oceny recenzowania). Taki system oceny reputacji zaproponowali Dennis i Owen (2015). Opiera się on na stworzonym nowym łańcuchu bloków do przechowywania jednowymiarowego wskaźnika reputacji (tzn. 0 lub 1) tworzonego na podstawie zrealizowanych transakcji.

Kolejny, podstawowy obszar zastosowań łańcuchów bloków w publikowaniu naukowym obejmuje tworzenie transparentnych, systematycznych sposobów oceny jakości i wpływu artykułów naukowych oraz innych publikacji. Obecnie stosowane rozwiązania w tym zakresie są krytykowane (Ietto-Gillies, 2008), są też podejmowane próby tworzenia nowych rozwiązań, na przykład różnego rodzaju indeksów i miar alternatywnych (Haustein, Bowman, Costas, 2016). Rozwiązania oparte na stosowaniu technologii blockchain, zarządzanej przez uczelnie wyższe i agendy rządowe, mogą spowodować powstanie transparentnej, systematycznie rozwijanej struktury oraz systemu procesów i algorytmów, służących organizacji informacji o wszystkich publikacjach i ich wydawcach. W tym celu należy przygotować i udostępnić wiele algorytmów oceny jakości artykułów, autorów i wydawców. Algorytmy mogą być dostępne jako inteligentne kontrakty, dzięki czemu interesariusze mają wgląd w metody obliczania miar jakości na wszystkich poziomach. W szczególności w funkcje obliczania miar w transparentny sposób może być włączona informacja o procedurach recenzowania i kosztach publikowania w różnych wydawnictwach/czasopismach. Dostępność wiarygodnych rozwiązań opartych na technologii blockchain, służących organizacji informacji w formie miar jakości, przyniesie istotne korzyści społeczności nauki w formie dokładniejszej oceny wpływu prac naukowych oraz stworzenia podstaw decyzji związanych z publikowaniem informacji naukowej oraz z finansowaniem badań. Warto zaznaczyć, że systemy pracujące w ten sposób opierają się na stosowaniu zasad otwartości i rozwiązaniach sterowanych konsensusem. Stosowanie blockchain powoduje, że informacja i algorytmy są otwarte dla publiczności, dzięki czemu możliwe jest odtworzenie i analizowanie procesów obliczania takich miar, jak impact factor dla czasopism lub $h$-index dla naukowców. 
Łańcuchy bloków mogą być stosowane do obsługi konkursów, ofert, recenzji, głosowań itp., związanych z przyznawaniem funduszy na badania. Mogłoby to funkcjonować na kilka sposobów. Po pierwsze, propozycje grantów mogą być obsługiwane podobnie jak propozycje publikacji nadsyłane do redakcji czasopism. Wydaje się, że najważniejszym problemem w tym przypadku jest zapewnienie uczciwości procedur wyboru propozycji w sytuacji, gdy panuje duża konkurencyjność, a dodatkowo są one komplikowane przez konflikty interesów wynikające z tego, że naukowcy konkurujący o fundusze nawzajem oceniają swoje propozycje. Po drugie, naukowcy jak najszerzej reprezentujący środowisko badaczy mogą głosować w sprawie finansowania nowych kierunków badań. Po trzecie, agencje dysponujące funduszami mogą same ogłaszać konkursy na finansowanie wybranych kierunków badań, między innymi na podstawie przeprowadzonych głosowań i analiz kierunków rozwoju nauki. Mogą one także zapraszać naukowców na podstawie informacji o ich osiągnięciach, uzyskiwanych poprzez platformy blockchain. Głosowania są jednym z podstawowych obszarów zastosowań technologii blockchain. Ogólnie mówiąc, mogą one spowodować spłaszczenie piramid hierarchicznych w nauce, co pozwala na większy wpływ społeczności naukowców na awanse, procesy publikacyjne itp.

Walidacja uczestników transakcji w łańcuchu bloków powoduje, że jednostki i organizacje postępujące wbrew zasadom badań naukowych będą miały utrudnione działanie. W przypadku działań wątpliwych lub nieetycznych odpowiedni węzeł łańcucha może zostać usunięty lub może stracić uprzywilejowaną pozycję. Uczestnicy mogą także funkcjonować autonomicznie, uzyskując pozycję w środowisku w wyniku konsensusu tworzonego na podstawie ustalonych zasad dotyczących funkcjonalności, etyki i procedur.

Technologia blockchain wspomaga także zarządzanie własnością intelektualną i ochronę danych osobowych. Standardowo dane te są umieszczane w sposób zcentralizowany na serwerach dostawcy usług, co uwrażliwia je na ataki. Blockchain oferuje możliwość zwiększenia bezpieczeństwa danych przez tworzenie zdecentralizowanych systemów zarządzania danymi, zapewniającymi dostęp do własnych danych (Zyskind, Oz, Pentland, 2016). Proces przygotowania publikacji powoduje konieczność obsługi rosnącej liczby tego rodzaju danych. Gromadzenie w łańcuchu bloków informacji o dostarczonym tekście prowadzi do akumulacji danych osobowych związanych z kolejnymi etapami procesu redakcyjnego: recenzowania, uzupełnień, decyzji redakcyjnych, a w końcu publikacji przygotowanej do rozpowszechniania. $Z$ jednej strony, technologia, tam gdzie to potrzebne, wzmacnia transparentność działań, a $\mathrm{z}$ drugiej umożliwia pełną prywatność tam, gdzie niezbędna jest ochrona danych. Większość tych danych należy do autora, służy jego własnej konsumpcji i analizom, w tym samopoznaniu (ang. self-tracking). Jednocześnie należy zwrócić uwagę, że technologia blockchain może spowodować zastąpienie tradycyjnych relacji własnościowych w społeczeństwie (czyli 
sposobów i zasad zarządzania własnością) modelami obsługiwanymi przez blockchain (Ishmaev, 2017).

Posiadanie uprawnionego dostępu do własnych danych osobowych bardzo zmienia sytuację między innymi w zakresie publikowania naukowego. Autorzy mogą selektywnie dobierać i scalać własne dane, określając swoje intencje. Intencje w tym znaczeniu są rozumiane jako chęć działania z wykorzystaniem niezbędnych do tego danych wspomagających intencje (Novotny i in., 2018, s. 169). Przykładem może być działanie rady programowej czasopisma. Jej członkowie są zazwyczaj wybierani na początku działalności, bez szczegółowej wiedzy o ich umiejętnościach lub nawet obszarach zainteresowań. Z wykorzystaniem opisywanej technologii każdy członek rady programowej mógłby wyrażać i opisywać swój obszar zainteresowań, wskazywać na związane z nim prace własne lub oceny zebrane w roli recenzenta, wskazujące również na niedostatecznie wykorzystywane zdolności i umiejętności. W taki sposób przewodniczący rady jest w stanie lepiej określić zakres działalności czasopisma, poszukiwać osób mających brakujące kompetencje oraz przygotowywać zaproszenia do publikowania (ang. call for papers) odpowiednie do kompetencji rady programowej. Tego typu intencje mogą być także stosowane do określania autorstwa publikacji, dokładnego określania specjalizacji oraz łączone z zewnętrznymi łańcuchami bloków, co pozwala na wykrywanie konfliktów interesów na podstawie stwierdzenia wcześniejszego współautorstwa lub innego rodzaju współpracy.

\section{Wnioski i podsumowanie}

W artykule zostały przedstawione możliwości zastosowania technologii blockchain w zarządzaniu mediami na przykładzie komunikacji naukowej, a dokładniej w publikowaniu naukowym. Jest to zagadnienie epistemologiczne, gdyż dotyczy punktu widzenia na technologię blockchain jako nowego zjawiska w świecie (Sfetcu, 2019). Technologia ta posiada ontologiczny status nowości, chociaż zarówno składa się z modeli, koncepcji i obiektów wcześniej znanych (innowacja podtrzymująca), jak i zawiera elementy innowacji zaburzającej. $Z$ jednej strony blockchain jest nowym elementem rzeczywistości, ale $\mathrm{z}$ drugiej jest także powiązany $\mathrm{z}$ wieloma dotychczasowymi aspektami naszego myślenia o nas samych i działania w otaczającej rzeczywistości, zarówno w jej części fizycznej, jak i wirtualnej. Dodatkowo technologia ta, jak inne technologie, konotuje możliwości kształtowania i kreowania rzeczywistości. Zastosowany w rozwiązaniach szczegółowych blockchain może stworzyć nową erę przetwarzania sieciowego, którego zasadniczą cechą będzie bezpieczny transfer $\mathrm{w}$ systemach obliczeniowych wiarygodnej informacji o rzeczach fizycznych i wirtualnych, realizowany w sposób zautomatyzowany.

W publikowaniu naukowym, opartym na technologii blockchain, także jest widoczne połączenie wcześniejszej wiedzy z nową. Dlatego celem artykułu było 
przedstawienie modelu opisującego możliwości zorganizowania przepływu informacji tekstowej w formie artykułów naukowych (znane rozwiązanie) w procesie publikowania za pomocą łańcucha bloków i kryptowalut (nowe zastosowanie). Czasopismo naukowe jest szczególnie predestynowane do stosowania tych technologii, gdyż ich inherentną częścią są procesy oceny jakości, gromadzenia i rozpowszechniania informacji, kluczowe dla publikowania naukowego. Zastosowanie opisanych technologii umożliwia zwiększenie transparentności tych procesów oraz otwartości informacji, dzięki czemu stają się one podstawą stosowania technologii Linked Open Data.

Technologie rozproszonych rejestrów (DLT), szczególnie w połączeniu z kryptowalutami, opartymi na tych technologiach, mają potencjał narzędzia służącego dokonaniu istotnych zmian w publikowaniu naukowym. Technologia blockchain pozwala na stosowanie uwiarygodnionych informacji oraz ułatwia współpracę bez potrzeby tworzenia scentralizowanych struktur zarządzania i autoryzacji. Kompetencje autoryzacji są przenoszone $\mathrm{z}$ instytucji, takich jak wydawnictwa i biblioteki, do systemów komputerowych, ich algorytmów, co powoduje, że rzeczywistość jest konstruowana w coraz większym zakresie z elementów obliczeniowych (Velasco, 2017). Dzięki tym cechom blockchain powinien znaleźć szerokie zastosowanie w publikowaniu naukowym, którego celem jest operowanie na globalnie rozproszonej informacji, tworzonej przez geograficznie i przedmiotowo rozproszonych uczestników w celu zapewnienia możliwie ścisłych i bezpiecznych interakcji między nimi. $\mathrm{W}$ ten sposób technologia blockchain daje możliwości i narzędzia pozwalające na projektowanie nowych rozwiązań usuwających wady obecnie stosowanych technologii, co z kolei spowoduje znaczne transformacje i rozbudowę istniejących procesów oraz zasad działania z korzyścią dla światowej społeczności naukowej.

Zmienić mogą się role uczestników tych procesów. Znacznemu wzmocnieniu ulega pozycja członków środowiska naukowego (autorów, redaktorów, recenzentów), gdyż to oni dysponują funduszami, które mogą przeznaczyć na finansowanie procesu wydawniczego. Ograniczeniu może natomiast ulec rola wydawców, na co wskazują doświadczenia takich platform publikowania w technologii DLT, jak DECENT $^{18}$ i LBRY ${ }^{19}$. Mogą oni odnaleźć się w roli dostawców usług cyfrowych dla autorów i recenzentów w nowym środowisku zarządzanym przez platformy technologiczne. Oczywiście cały system nauki, w tym komunikacji naukowej, w dużej mierze nadal musi być finansowany z środków publicznych.

$\mathrm{Na}$ koniec trzeba zaznaczyć, że stworzenie niezawodnego systemu komunikacji naukowej na podstawie opisanych technologii, wymaga jeszcze wiele pracy, a w szczególności współpracy i znalezienia konsensusu przez przedstawicieli wszystkich zainteresowanych środowisk: naukowców (we wszystkich rolach), wydawców i agend finansujących. Uzyskanie tego konsensusu i rozwój współpracy

18 Zob. https:/decent.ch/.
19 Zob. https://lbry.com/. 
zależą od tego, czy blockchain jest rzeczywiście potrzebny i korzystny dla wszystkich interesariuszy. Obecnie są prowadzone prace eksperymentalne, obejmujące pojedyncze platformy i tytuły czasopism ${ }^{20}$. Nie mogą one jednak zaprezentować wszystkich zalet stosowanych rozwiązań, gdyż technologie sieci globalnych, takie jak blockchain i Linked Data, pełnię swoich możliwości ukazują dopiero wtedy, gdy ich stosowanie staje się powszechne (globalne właśnie). Nie jest jednak pewne, czy prywatne firmy wydawnicze, funkcjonujące we własnym środowisku komunikacyjnym, nastawione na zysk, zechcą współpracować z systemami, które wymagają oddania części autonomii w takich sprawach, jak koszty ogólne i składowe publikowania, opłaty za prace redakcyjne i recenzje, outsourcing decyzji redakcyjnych, nawet jeśli dzięki temu procesy te stałyby się bardziej zintegrowane, a przez to efektywne (Rayner, 2019, s. 265).

\section{Bibliografia}

Andersen J., Lomborg S. (2020). Self-tracking and Metric Codification in Digital Infrastructures for Scholarly Communication. „The Information Society”, 36(1), s. 43-52.

Bower J., Christensen C. (1995). Disruptive Technologies: Catching the Wave. „Harvard Business Review", 73(1), s. 43-53.

Burley R. (2018). Stable and Decentralized? The Promise and Challenge of a Shared Citation Ledger. „Information Services \& Use”, 38(3), s. 141-148.

Casper C. (2016). The Online Research Article and the Ecological Basis of New Digital Genres [w:] A. Gross, J. Buehl (eds.), Science and the Internet: Communicating Knowledge in a Digital Age. New York: Routledge.

Cisek S., Sapa R. (2007). Komunikacja naukowa w Internecie: mity i rzeczywistość [w:] W. Lubaszewski (red.), Komputer - człowiek - prawo. Ksiegga pamiątkowa WZiKS UJ. Kraków: Wydawnictwo Uniwersytetu Jagiellońskiego.

Coelho F., Brandão A. (2019). Decentralising scientific publishing: can the blockchain improve science communication? „Memórias do Instituto Oswaldo Cruz”, 114, e190257.

Dennis R., Owen G. (2015). Rep on the Block: A Next Generation Reputation System Based on the Blockchain [w:] $10^{\text {th }}$ International Conference for Internet Technology and Secured Transactions (ICITST), London, 14-16 December 2015. London: IEEE.

Dillenberger D., Nowotny P., Zhang Q. (2019). Blockchain Analytics and Artificial Intelligence. „IBM Journal of Research and Development”, 63(2-3), 5.1-5.14.

Dudek D. (2017). Możliwości wykorzystania technologii Blockchain w obszarze edukacji. „Informatyka Ekonomiczna”, 3(45), s. 55-65.

Fu M. (2020). Integrated technologies of blockchain and biometrics based on wireless sensor network for library management. „Information Technology and Libraries”, 39(3), s. 1-13.

Haustein S., Bowman T., Costas R. (2016). Interpreting "Altmetrics": Viewing Acts on Social Media through the Lens of Citation and Social Theories [w:] C. Sugimoto (ed.), Theories

20 Powstawało wiele projektów dotyczących zastosowania łańcucha bloków w nauce, które oferowały platformy publikacyjne, szczególnie Open Access (np. scienceroot.com, eurekatoken.io, pluto. network, orvium.io); duża ich część zakończyła się niepowodzeniem (Kosmarski, 2020). 
of Informetrics and Scholarly Communication: A Festschrift in Honour of Blaise Cronin. Berlin-Boston: De Gruyter.

Hughes K. (2017). Blockchain, the Greater Good, and Human and Civil Rights. „Metaphilosophy", 48(5), s. 654-665.

Ietto-Gillies G. (2008). A XXI-Century Alternative to XX-Century Peer Review. „Real-World Economics Review", 45, s. 10-22.

Ishmaev G. (2017). Blockchain Technology as an Institution of Property. „Metaphilosophy”, 48(5), s. 666-686.

ISO/IEC 24760-1 (2019). IT Security and Privacy - A Framework for Identity Management Part 1: Terminology and Concepts.

Janowicz K. i in. (2018). On the Prospects of Blockchain and Distributed Ledger Technologies for Open Science and Academic Publishing. „Journal of Semantic Web”, 9(5), s. 545-555.

Jaradeh M. i in. (2019). Open Research Knowledge Graph: Towards Machine Actionability in Scholarly Communication [w:] M. Kejriwal, P. Szekely, R. Troncy (eds.), Proceedings of the $10^{\text {th }}$ International Conference on Knowledge Capture, K-CAP 2019, Marina del Rey, CA, USA, 19-21 November. New York: ACM.

Johnson J., Manion S. (2019). Blockchain in Healthcare, Research, and Scientific Publishing. "Medical Writing”, 28(4), s. 10-13.

Jun M. (2018). Blockchain Government - A Next Form of Infrastructure for the Twenty-First Century. „Journal of Open Innovation: Technology, Market, and Complexity”, 4(1), art. 7. https://doi.org/10.1186/s40852-018-0086-3 (dostęp: 17.06.2021).

Kim H., Laskowski M. (2018). Toward an Ontology-Driven Blockchain Design for Supply Chain Provenance. „Intelligent Systems in Accounting, Finance and Management”, 25(1), s. $18-27$.

Kochalko D. (2019). Making the Unconventional Conventional: How Blockchain Contributes to Reshaping Scholarly Communications. „Information services \& Use”, 39(3), s. 199-204.

Kosmarski A. (2020). Blockchain Adoption in Academia: Promises and Challenges. „Journal of Open Innovation: Technology, Market, and Complexity”, 6(4), art. 117. https://doi. org/10.3390/joitmc6040117 (dostęp: 17.06.2021).

Kosmarski A., Gordiychuk N. (2020). Token-curated Registry in a Scholarly Journal: Can Blockchain Support Journal Communities? „Learned Publishing”, 33(3), s. 333-339.

Lakoff G., Johnson M. (2011). Metafory w naszym życiu. Warszawa: Wydawnictwo Naukowe PWN.

van Lier B. (2017). Can Cyber-Physical Systems Reliably Collaborate within a Blockchain? „Metaphilosophy”, 48(5), s. 698-711.

Liu L., Gee H. (2017). Determining Whether Commercial Publishers Overcharge Libraries for Scholarly Journals in the Fields of Science, Technology, and Medicine, with Semilogarithmic Econometric Model. „Library Quarterly”, 87(2), s. 150-172.

Mackey T., Shah N., Miyachi K., Short J. Clauson K. (2019). A Framework Proposal for Blockchain-Based Scientific Publishing Using Shared Governance. „Frontiers in Blockchain”, 2, art. 19.

Markowski K. (2019). Kryptowaluty. Powstanie - typologia - charakterystyka. „Civitas et Lex”, 23(3), s. 69-82.

Nakamoto S. (2008). Bitcoin: a Peer-to-Peer Electronic Cash System. https://bitcoin.org/bitcoin. pdf (dostęp: 17.06.2021).

Nierenberg B. (2013). Zarządzania mediami - koncepcje i metody badawcze. „Współczesne Zarządzanie", 12(2), s. 41-47. 
Niya S., Pelloni L., Wullschleger S., Schaufelbühl A., Bocek T., Rajendran L., Stiller B. (2019). A Blockchain-Based Scientific Platform [w:] $1^{\text {st }}$ IEEE Intern. Conference on Blockchain and Cryptocurrency (ICBC). Seoul, 14-17 May 2019. New York: IEEE.

Noorden R. (2014). Global Scientific Output Doubles Every Nine Years. Nature news blog, 7.05.2014, http://blogs.nature.com/news/2014/05/global-scientific-output-doubles-everynine-years.html (dostęp: 17.06.2021).

Novotny P., Zhang Qi, Hull R., Baset S., Jim Laredo J., Vaculin R., Ford D., Dillenberger D. (2018). Permissioned Blockchain Technologies for Academic Publishing. „Information Services \& Use", 38(3), s. 159-171.

Owen J. M. (2007). The Scientific Article in the Age of Digitization. Dordrecht: Springer Verlag.

Prosser D. (2003). Scholarly Communication in the $21^{\text {st }}$ Century - the Impact of New Technologies and Models. „Serials”, 16(2), s. 163-167.

Raynard M. (2017). Understanding Academic E-Books through the Diffusion of Innovations Theory as a Basis for Developing Effective Marketing and Educational Strategies. "Journal of Academic Librarianship", 43(1), s. 82-86.

Rayner S. (2019). Academic Publishing [w:] A. Phillips, M. Bhaskar (eds.), The Oxford Handbook of Publishing. Oxford: Oxford University Press.

Rossum J. (2017). Blockchain for Research. Perspectives on a New Paradigm for Scholarly Communication. London: Digital Science.

Rubel D. (2019). No Need to Ask: Creating Permissionless Blockchains of Metadata Records. „Information Technology and Libraries", 38(2), s. 11-17.

Sfetcu N. (2019). Philosophy of Blockchain Technology: Ontologies. Drobeta-Turnu Severin: MultiMedia Publishing.

Sompel H. van de, Payette S., Erickson J., Lagoze C., Warner S. (2004). Rethinking Scholarly Communication: Building the System That Scholars Deserve. „D-Lib Magazine”, 10(9), http// www.dlib.org/dlib/september04/vandesompel/09vandesompel.html (dostęp: 17.06.2021).

Swan M., de Filippi P. (2017). Toward a Philosophy of Blockchain: A Symposium. „Metaphilosophy", 48(5), s. 603-619.

Tarkhanov I., Fomin-Nilov D., Fomin M. (2021). Crypto Access: Is It Possible to Use Cryptocurrencies in Scholarly Periodicals? „Learned Publishing”, 34(2), s. 253-261.

Velasco P. (2017). Computing Ledgers and the Political Ontology of the Blockchain. „Metaphilosophy", 48(5), s. 712-726.

Zheng Z. i in. (2018). Blockchain Challenges and Opportunities: A Survey. „International Journal of Web and Grid Services", 14(4), s. 352-375.

Zyskind G., Oz N., Pentland, A (2016). Decentralizing Privacy: Using Blockchain to Protect Personal Data [w:] IEEE CS Security and Privacy Workshop (SPW). 21-22 May 2015. San Jose, CA: IEEE. 
